\title{
Sir Henry Solomon Wellcome and Dr Andrew Balfour: an enterprise on the Nile and the early foundation of public health and medical research in the Sudan (1899-1935)
}

\author{
TA Elhadd \\ Alwakra Diabetes Centre, Hamad Medical Corporation, Doha, Qatar
}

\begin{abstract}
In Sudan, modern medical practice and medical research began soon after the creation of Anglo-Egyptian Sudan at the turn of the 20th century. The benevolent involvement of Sir Henry Solomon Wellcome, and the ingenious feat of his protégé Sir Andrew Balfour, was crucial to the strong foundation of that establishment. Sir Henry Wellcome provided the financial sponsorship plus influential, logistical and moral support. Dr Balfour put great energy into making the enterprise one of the most amazing medical achievements in colonial medicine. Improvement in the public health of the capital Khartoum was emulated by other doctors working in this vast country. Research was not restricted to tropical medicine; it also encompassed agricultural and chemical research. This helped with the establishment of the first modern medical school in the country in 1924 and resulted in the medical service in Sudan being described as one of the best in the world. Many British doctors flocked to Sudan to make a fortune and to set a path for their career back in Britain.
\end{abstract}

Correspondence to TA Elhadd Alwakra Diabetes Centre PO Box 3050 Hamad Medical Corporation Doha Qatar

e-mail tarikelhadd58@gmail.com

KEYWORDS Andrew Balfour, HenryWellcome, Sudan,Tropical Research Laboratory

DECLARATION OF INTERESTS No conflict of interest declared.

\section{INTRODUCTION}

Modern Sudan came into existence in 1820 following the invasion of the Sudanese territory by Mohamed Ali Pasha, the founder of modern Egypt. After ruling for six decades, his rule proved to be too corrupt and his tyranny and oppression were too much for the Sudanese to put up with. A revolution, led by al-Mahdi, a pious cleric, soon engulfed the country and the corrupt rulers were expelled. The era of the Mahdist State was characterised by military marches, tribal revolts, famine and several smallpox and cholera epidemics,' and eventually became vulnerable and failed to resist the rising imperial ambitions of the British. The involvement of the British imperial hero, Charles Gordon, added the required catalyst for the British involvement in the invasion of the Mahdist State. The desire of the British to extend their power into the heart of Africa and the race with other European powers, especially France, reached its climax when the Nile Expedition forces (a mixture of Egyptian and Sudanese troops and mainly British officers) led by Lord Kitchener succeeded in overthrowing the Mahdist Khalifa. The 'Reconquest' began in 1896 after a long build-up, and the final fate of Mahdist Sudan was sealed during the Battle of Omdurman when the Sudanese warriors, mainly armed with primitive weapons, were massacred by the modern armoury of the invading troops. Winston Churchill, who was a soldier and war correspondent during that expedition, was witness to the fatal bravery of the Sudanese. ${ }^{2}$

After the turbulent years of the Mahdist rule, the health and sanitation of the country were very backward as the earlier rudimentary health services established by the Turco-Egyptian rule ${ }^{3,4}$ had been swept away during the Mahdist revolt. Establishing public services, namely health and education, was at the heart of such policy. ${ }^{5}$

\section{HENRY WELLCOME AND HIS TROPICAL RESEARCH LABORATORIES IN KHARTOUM}

Henry Solomon Wellcome was destined to play a crucial role in the early establishment of health services and medical research in Sudan. Wellcome was born in Wisconsin in 1853 and his family settled in Garden City, Minnesota, where he was educated. His uncle, George Wellcome, was a doctor and, during his adolescence, young Henry helped out in his surgery and small dispensary attached to his clinic. During his time with his uncle the town was subjected to a fierce siege by the local Sioux Indians whose uprising resulted in the massacre of several hundred of the white settlers. The subsequent reprisal by the authorities resulted in many Sioux being killed and their chiefs hanged. Wellcome helped his uncle look after the dying and wounded; the experience leaving a deep impression on him and he 
later became very sympathetic to the plight of Native Americans and their cause. This very much sharpened his religious feeling. ${ }^{6}$

Wellcome graduated from the School of Pharmacy, Philadelphia University, and worked as a pharmaceutical salesman travelling to South America. In 1880, Wellcome was invited by one of his fellow Americans, Silas Burroughs, to join him in London to establish a company. This was named Burroughs Wellcome \& Co. Wellcome was quickly on the rise and in a short period he became a prominent figure in British business and public life. In 1884 the company first introduced medicines in tablet form to the UK and Wellcome registered the brand name 'tabloid'. Wellcome befriended the explorer, Henry Morton Stanley, as both attended May French-Sheldon's salon for travellers and explorers. ${ }^{6}$ Wellcome became deeply connected with the British colonial enterprises and the missionary activities destined for Africa. He mastered the art of 'business publicity' and soon began to publicise his own 'Tabloid Medicine Chest'.

The first medicine chest he used accompanied Stanley on his adventures to the basin of River Congo. According to his biographer, several factors drew Wellcome's interest to the events in the Sudan. Following a successful appeal made by Lord Kitchener to establish a school in Khartoum in memory of General Charles Gordon, the Gordon Memorial College was founded in 1900. Wellcome was one of the first Europeans to visit the Sudan following the Reconquest by travelling to Khartoum via Cairo in 1900 and the visit was a moving experience. Abdel-Hameed describes it thus: 'the start of the association between Wellcome and the Sudan was his Nile cruise soon after the Kitchener Reconquest in winter 1900/190I'? Wellcome recorded in his diaries the poor health and sanitation of the people of this newly annexed country and he echoed the initial thoughts of his future enterprise: 'It was my purpose to study the existing condition of the native people as well as observe their ethnographical characteristics...During my visit to one of the small islands of the Nile, just above the Shabaluka Cataract, there were perhaps thirty or forty inhabitants, everyone lying helplessly prostrated, weak and emaciated suffering from malaria in an extremely virulent form. I am sure that no one could have seen those mere skeletons of men, women and children without being moved by deep emotions to do something to mitigate the pitiful conditions of these poor and surely distressed people..... ${ }^{6}$

While in Khartoum, Wellcome made suggestions to Sir Reginald Wingate, the British Governor General of the Anglo-Egyptian Sudan, and ordered medicines and equipment for the dispensary he donated to the Gordon Memorial College. Wellcome went further and made proposals to establish a tropical research laboratory which he undertook to fully fund and equip. In a letter

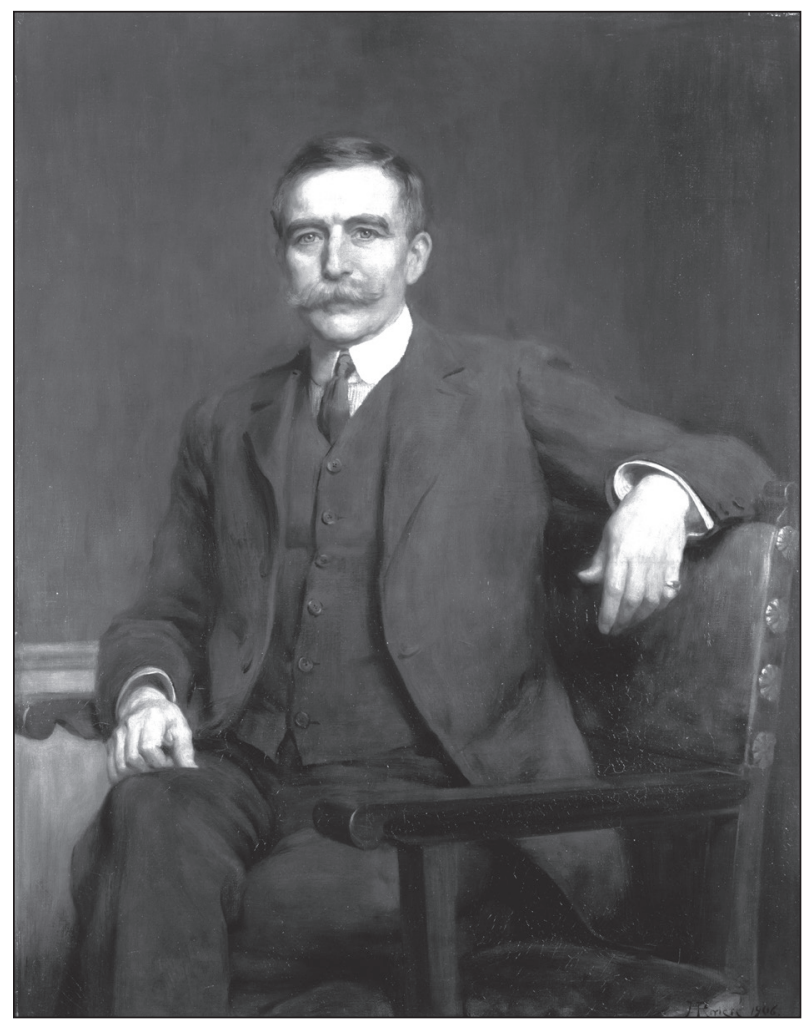

FIGURE I Henry Solomon Wellcome, 1906: three-quarter length. Oil painting by Hugh Goldwin Riviere, 1906. Wellcome Library, London

to Wingate, Wellcome made his offer on the 28th of September 1901:'Sir, I beg to offer for the acceptance of the Gordon Memorial College, Khartoum, complete equipment for chemical and bacteriological laboratories for analytical and research work ...'. Wellcome went on to set out the objectives of his historical proposals: 'To promote technical education. To study bacteriologically and physiologically tropical disorder, specially the infective diseases of both man and beast, particular to the Soudan, and to render assistance to the officers of health and to the clinics of civil and military hospitals... It is anticipated that the work in the laboratories will prove beneficial to both the Europeans and the native populations...but the government of Soudan is to support it and maintain it by providing the salary of its director and staff' .8

\section{ANDREW BALFOUR: FIRST DIRECTOR OF THE WELLCOME TROPICAL RESEARCH LABORATORY AND FIRST MEDICAL OFFICER FOR HEALTH, KHARTOUM I903-I9I2}

On his return to London, Wellcome became preoccupied with his new tropical venture in the Sudan. His first task was to identify and chose a dedicated director for the laboratory. His friend, Dr (later Sir) Patrick Manson suggested Dr Andrew Balfour, a young Scottish doctor from Edinburgh, whom Manson knew. Balfour was born in Edinburgh in 1873, studied at George Watson College, 


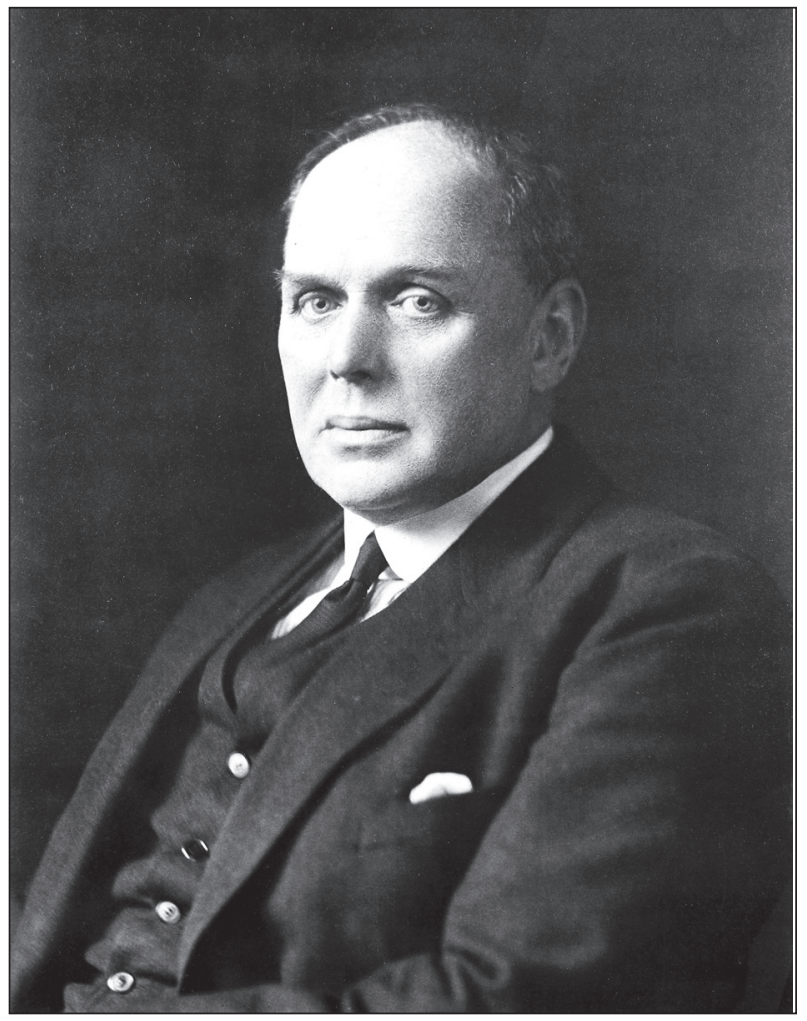

FIGURE 2 Sir Andrew Balfour. Wellcome Library, London.

qualified from Edinburgh University with a Bachelor of Medicine in 1894, and went on to obtain a Master of Surgery from Cambridge in 1897. He then obtained his MD from Edinburgh University and later obtained a diploma in public health under the guidance of Manson himself, and served in the South African War as a surgeon. He had all the qualities Wellcome was looking for.Wellcome wrote to Mr James Currie, the Principal of Gordon Memorial College, and director of education in Sudan: 'Penton and I interviewed the candidates for the position of director and bacteriologist. The only two candidates, who are likely to be satisfactory, are both married men. Of these... Dr Paton and I agree in favour of Dr Andrew Balfour ...?

Wellcome organised a farewell party for Balfour in a prestigious restaurant in Piccadilly, London, which was attended by a distinguished audience including several scientists who had a special interest in tropical medicine and the Sudan. Among those were Balfour's mentor, Patrick Manson, and Henry Morton Stanley. Balfour's mission in the Sudan would now begin. Balfour spent a few weeks in Cairo where he had the opportunity of visiting Qasr Alini Hospital. Here he chose his laboratory assistant, Mr John Newlove, who would later prove to be a very useful aide to Balfour's ventures in public health and research in tropical medicine. In January 1903, on arrival in Khartoum, Balfour was appointed immediately as Medical Officer for Health in addition to his capacity as the Director of the Wellcome Tropical Research Laboratory (WTRL). Balfour set out his priorities to

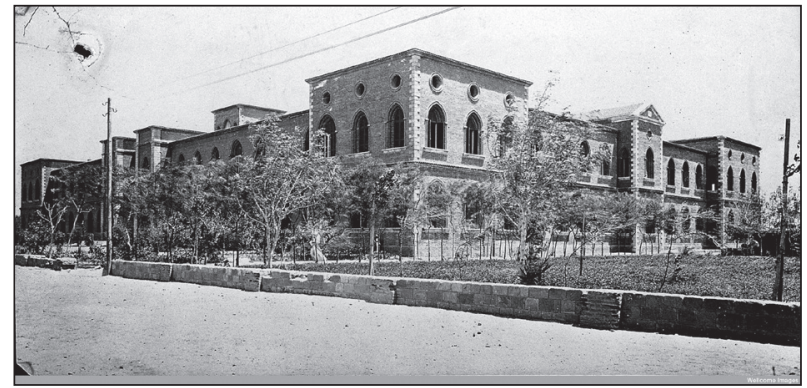

FIGURE 3 Gordon-Memorial College. Wellcome Library, London

improve the public health of Khartoum and his input into the health and sanitation of Khartoum in a relatively short period was extraordinary. The laboratory consisted of only five rooms, one being used as Director's office and one used as a museum. The staff consisted of Balfour and John Newlove together with two Sudanese assistants.

\section{BALFOUR'S QUEST FOR CONTROL OF MALARIA AND MOSQUITO ERADICATION}

Balfour began to set out his priorities and identified four major areas where change was needed. He felt that his first task was to eradicate mosquitoes and control malaria which was devastating to the inhabitants. ${ }^{10}$ When he started his routine laboratory work, Balfour discovered that, in the various blood slides he examined, the major forms of malaria were malignant tertian, quartan and benign tertian. The task to eradicate malaria was to focus on finding its breeding sites, and then to tackle this via a group of 'sanitary workers' who were not currently available in the country. At the time, the concept of the 'Mosquito Brigade' was well known in imperial medical circles. Balfour's efforts very much coincided with the efforts of other British personnel who were involved in improving the state of public health in Khartoum; Colonel Talbot, of the Royal Engineers, and Colonel Lyle Cummins, Senior Medical Officer of Khartoum from the Royal Army Medical Corps. Colonel Talbot initiated some preliminary discussions with Colonel Cummins as both were aware of Major Ronald Ross's work on mosquito control in India.

In 1892, Ross, while working for the Indian Medical Service, had discovered how the anopheline mosquito transmitted malaria, a work which won him the Nobel Prize in 1902. Ross designed an ingenious method of curbing the mosquito transmission and controlling malaria initially in India, and later in West Africa, Egypt and Cyprus.This method proved to be effective wherever it was applied, and it became widely known in British colonial circles. Balfour was asked to take the matter to the fore. He wrote:'Colonel Talbot being much interested in the matter, it was not long before one was asked to send to the SMO, Khartoum, a statement regarding the 
formation of a 'Mosquito Brigade', and one was subsequently requested to take complete charge of the work. I was very glad to do so, as it gives me an opportunity of studying the mosquito and their breeding places, of collecting specimens and of carrying some experiments...two intelligent natives were chosen from Colonel Stanton, the Mudir, and quickly trained to recognize mosquitoes, their eggs, larvae and pupae and to distinguish the culicidae from other insects'."

Balfour's first task proved to be a painstaking one. The first place that gave him some food for thought was the backyard of the Grand Hotel where there was a well that provided the water to the hotel and Balfour realised it was one of the potential sites for mosquito breeding. Balfour then traced the source of the breeding sites to the 600 wells and waterways in various parts of Khartoum. In the essay he wrote for the Wellcome First Report in 1904, Balfour described the various types of common mosquito in Khartoum including Culex fatigans and several other species of anopheline mosquito that transmitted the deadly malaria parasite, the microfilaria of elephantiasis and the genus Stegomyia fasciata that transmitted the yellow fever virus. ${ }^{12}$ This was later traced to the bilges of the river steamers that traversed the Nile from Southern Sudan.

Balfour adopted the concept of the 'Mosquito Brigade', first pioneered by Ross in India. Initially, Balfour and Newlove made several innovations as well as modifying ideas and techniques available at the time. Balfour's 'Brigade', which consisted primarily of two Sudanese men recruited from Colonel Stanton's department, were described by Balfour:'... they were quickly trained to recognize mosquitoes, their eggs, larvae and pupae, and to distinguish the culicidae from other insects. $\mathrm{Mr}$ Newlove, the laboratory assistant... was placed in charge of these men'. ${ }^{2}$ The initial plan of the Mosquito Brigade was to attack the mosquitoes at the larval stage. The breeding places, after initial research, were found to be the wells, Sakia pits (Arabic: simple irrigation tool), garden tanks (primarily at the riverfront), bath waste pits, Zeers (Arabic: earthenware pots used to store and filter water for drinking and domestic use), permanent garden pools and pools left in the banks by the falling Nile. The Mosquito Brigade was to go round in the mornings and again in the afternoons, inspecting wells, taking samples of water which were examined for egg boats, larvae and pupae. Wells found to be infested were sprayed with a mixture of petroleum distillate which Balfour found to be safe to both human and animals, non-volatile and effective. The Brigade would then revisit all water sources, including zeers in households as, during his surveys, Balfour found that zeers were important reservoirs for mosquito breeding.

Another task Balfour faced was dealing with the water vessels which accompany the Nile steamers. These vessels were a dreaded source of 'imported malaria'. At the time, many were travelling up and down the country, and those that traversed the Southern frontiers were the most notorious in bringing the deadly mosquito. The risk did not involve only transmission of malaria, but also yellow fever. Balfour, Newlove and their Mosquito Brigade tried several measures including crude petroleum distillate and fumigation with sulphur squibs. Other measures included the task of educating the crew and engineers of these vessels to deal with adult insects. Such measures were successful as a way to keep the mosquito at bay. In 1906, Balfour wrote in the Second Wellcome Report; 'I have not seen a living wild adult Anopheline in Khartoum for more than a year and a half and I am always on the outlook for these insects'. ${ }^{2}$

In the summer of 1903, at the start of the campaign against mosquitoes, around $50 \%$ of the wells in Khartoum were found to be infected and that was reduced to $9.5 \%$ after six months of hard work, and then to $3.6 \%$ after a year. ${ }^{12}$ Over the years, and despite only having a small workforce and sparse financial resources, Balfour and his Mosquito Brigade pressed on with their efforts to control malaria and eradicate mosquitoes. Their perseverance was not without reward; the mosquito was eradicated and the incidence of malaria dropped to its lowest levels in under one year. ${ }^{12}$ Lt-Colonel Penton, Principal Medical Officer of the Egyptian Army, commented in his 1903 Report that Balfour had 'waged a vigorous campaign against mosquitoes'. ${ }^{3}$ By 1906 Khartoum was a clean healthy city and this public health achievement was not confined to the capital. Balfour was asked by the SMO how his work could be emulated by other Royal Army Medical Corps members who were in charge of the various provinces.

Balfour's second task was to handle the issue of sewage collection and its disposal. He abolished the use of the Crowley cart and replaced it with latrine buckets. ${ }^{14}$ The bucket contents were disposed of in trenches outside the southern part of Khartoum and secure measures were made to ensure their safe and effective transport to the disposal sites. Such disposal kept diseases such as dysentery and enteric fever to a minimum, and reduced the number of flies breeding. This system of sewage disposal adopted by Balfour continued to be in use in Khartoum (and many other Sudanese cities and towns) until the 1960s and early 1970s when it was finally abolished.

Balfour and Newlove's next priority was refuse collection and disposal. Balfour proposed the creation of large pits to collect waste water, and those large pits were cemented by covers, the water was collected by hoses and pumps and the pits later drained and the wastewater disposed outside of the town. Other public health endeavours conducted by Balfour were to ensure safe 


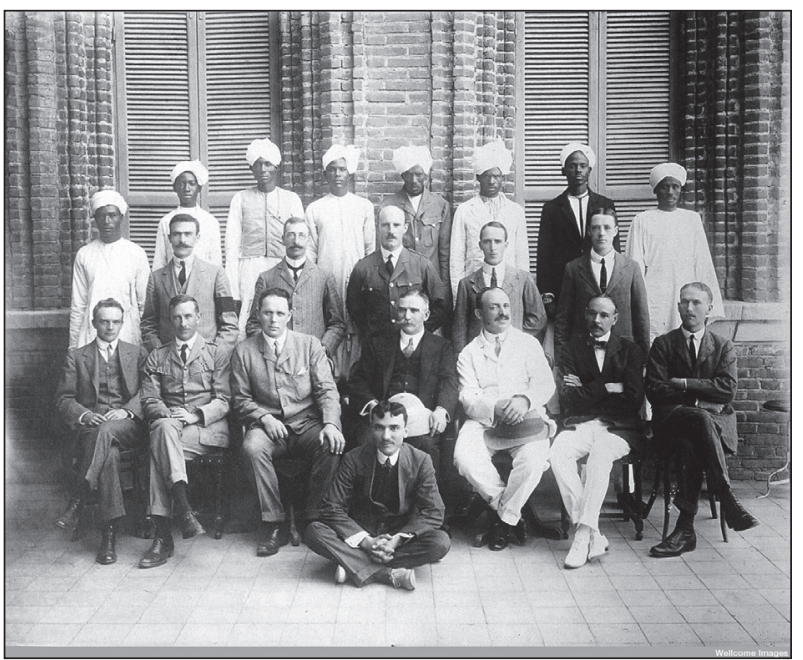

FIGURE 4 Staff of the Wellcome Tropical Research Laboratory, Khartoum, including Henry Wellcome and Andrew Balfour. Wellcome Library, London.

water supply, clean and healthy meat and milk provisions. Again, novel measures were made and brilliantly executed and supervised. To ensure proper implementation of the measures, legislation was strictly imposed. The research facilities of the WTRL were used to the best cause, ensuring those ventures were backed up by scientific means. As communicable diseases were so rampant at that time, the best remedy was to prevent them as modern drugs and treatments were not yet available. The outcome was a clean healthy town, and it remained as a prototype in the African British colonial mosaic.

\section{ANDREW BALFOUR AND THE EARLY FOUNDATION OF MEDICAL RESEARCH IN THE SUDAN}

Andrew Balfour's novel research into entomology was greatly assisted by other members of the Royal Army Medical Corps who were in the habit of conducting military and medical missions in various branches and tributaries of the River Nile. The task of finding and mapping out different types of mosquitoes was one of the first public health tasks for Balfour. It was the backbone of his work to eradicate mosquitoes, curb malaria and prevent the potential spread of other mosquito-borne diseases such as yellow fever, Dengue fever, and filariasis. The various types of mosquitoes he identified to be widespread in Khartoum, were Culex fatigans, which he first discovered in the wells of the Grand Hotel in Khartoum.

Next, he discovered the major anopheline genus which was also highly prevalent in Khartoum, Pyrotophrus costalis. This is a malaria vector, and a second one he discovered was Stegomyia fasciata, a vector of yellow fever. ${ }^{15}$ The quest to map the presence of various types of mosquitoes took place along the banks of the Nile

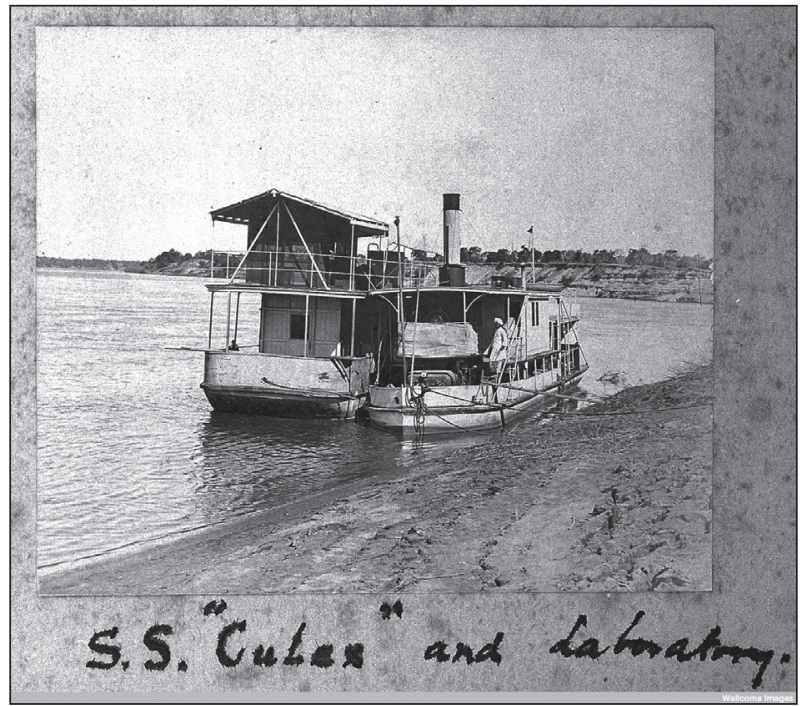

FIGURE 5 Steamship Culex and floating laboratory on the Nile. Photograph by R.G. Archibald, 1911. Wellcome Library, London

from Dongola down to the Pibor, Rosiers, the Lado Enclave and the hinterlands of Bahr el-Ghazal. Early entomology work was published in the First Report in 1904. Balfour wrote an article on 'Biting and noxious insects other than mosquitoes'16 and followed this with a report bearing the same title in the Second Report. ${ }^{17}$ In the first report, Balfour pointed to a discovery which 'has to be chronicled verbatim'. He meant to point to the important discovery by Lt-Colonel Griffith who, after been provided with a small entomological outfit prior to a trip up the White Nile, brought specimens of several insects to the laboratory and among them was Glossina moristans.

That discovery of the tsetse fly was a landmark which alerted the government to the potential presence or spread of the deadly sleeping sickness in the southern frontier. Dr Fred $\mathrm{V}$ Theobald, one of the most eminent British entomologists of his time, wrote a comprehensive article about the mosquitoes of the Sudan. ${ }^{18}$ Theobald had earlier examined in detail the various mosquitoes which had been collected by Balfour and his colleagues, and he described some of the new species discovered. Among these was a culex that resembled Culex fatigans (a known vector of yellow fever), which was named $C$. pallidocephala. A second one was discovered by Captain Lyle Cummins and named after him (C. cumminsii). Several new anopheline mosquitoes were discovered by Balfour; one was named after Wellcome (A. wellcomei), and another new member of the genus Uranotaenia was named after Balfour himself (U. balfouri).

Balfour's contribution to other fields of parasitology was impressive and he discovered new species in this field. He discovered a new blood parasite which he stumbled upon while examining blood specimens of the jerboa. Balfour observed that there were peculiar intra- 
corpuscular parasites in the red blood cells of this animal, while conducting some work on trypansomiasis (a work which he extensively researched while in Khartoum). Balfour wrote in the Second Report of the WTRL: 'while carrying out work in connection with trypanosmiasis, I have had to make occasions of numerous examination of the blood of the jerboa or desert rat...in the first blood examined I was surprised to see that a large proportion of red blood corpuscles harboured an unpigmented and non-motile parasite... In the stained specimens it was at once apparent that we are dealing with some kind of trophozoite'. ${ }^{19}$ He sent a specimen to Professor Charles Laveran (the French Nobel Laureate and discoverer of the plasmodium of malaria and the trypanosome of sleeping sickness) who 'declared the parasite to be a haemogregarine, and has kindly informed me that the discovery is one of much interest'. Professor Lavern named the parasite $H$. balfouri after Balfour. ${ }^{20}$

\section{THE TRAVELLING PATHOLOGISTS AND THE FLOATING LABORATORY}

Wellcome's involvement with his laboratory in Khartoum did not cease following his donation. Knowing the generosity of Wellcome and his willingness to provide ongoing support, Balfour embarked on further ventures exploring frontiers of tropical medicine beyond his base at the WTRL. Early research focused primarily on sleeping sickness (trypanosomiasis), a threat which was spreading to southern Sudan from neighbouring Uganda and the Belgian Congo. Balfour proposed the idea of a visiting pathologist to the Sudanese Government and to Wellcome, who was obviously in support of his protégé's proposal. Dr Sheffield Neave, a pathologist from the London School of Tropical Medicine, was selected to go to Khartoum with a specific mandate to travel up the White Nile in the capacity of a 'traveling pathologist'. During his time in the Sudan, Neave carried out research in tropical endemic tropical diseases. He described the first proven case of leishmaniasis after he saw the parasite in a splenic puncture in a child in Omdurman. ${ }^{21}$ He made valuable observations from his travels up the White Nile and gathered many specimens of rare insects, native medicines and parasites, some of them were hitherto undescribed. ${ }^{2}$ Dr Neave wrote a landmark report on his scientific voyages and this was published in the Second Wellcome Report. ${ }^{22}$

Wellcome's enterprises with his laboratory took another major step when he was approached by the great Egyptologist, Dr (later Sir) Ernest Alfred Wallis Budge, of the Department of Egyptian and Assyrian Antiquities at the British Museum. Budge, who visited Sudan and met Balfour, suggested to Wellcome that he explore the possibility of providing a 'floating laboratory' in addition to the parent laboratory in Khartoum. ${ }^{23}$ Balfour pointed out that the addition of a 'floating laboratory' would add much benefit to the scientific work they were trying to do. He stressed that the difficulty with obtaining pathological specimens in a viable and intact state would be boosted. ${ }^{24}$ The idea was appealing to Wellcome, who had had a similar experience by fitting out a hospital ship during the South African War and the floating laboratory became a reality early in 1907.The Sudanese Government built the barge at Khartoum shipyard and Henry Wellcome provided the fittings and equipment at his own expense. The Khartoum Laboratory and the London School of Tropical Medicine jointly staffed the floating laboratory and planned the medical research. ${ }^{25}$

The first voyage of the floating laboratory was undertaken by $\mathrm{Dr}$ Charles MorleyWenyon, a distinguished pathologist who, like Balfour, was a protégé of Sir Patrick Manson. On that first journey he traversed the White Nile and its tributaries up and down southern and central Sudan. He built on the work carried out by Sheffield Neave, especially his research into sleeping sickness. Wenyon had the advantage of onsite laboratory equipment to further explore this deadly disease, and to expand the research of other diseases, especially leishmaniasis; the latter proved to be a significant endemic disease in most parts of the Sudan. Wenyon also conducted research on other tropical parasitic diseases and confirmed the earlier work of Fritz Schaudinn, a German bacteriologist, on the life cycle of Entamoeba histolytica; the parasite of amoebic dysentery. Wenyon conducted some of the earliest research into malaria in southern Sudan and also described cases of leprosy and mycetoma. ${ }^{26}$ In the same report he asserted that syphilis was common in the southern Sudanese, even in children as young as ten. The floating laboratory proved to be an invaluable tool during the work of the Kala Azar Commission, which helped to map out the epidemiology of the disease in the Blue Nile and adjacent parts of south eastern Sudan. Charles Seligman and his wife made use of the vessel during his work studying the Nilotic tribes of southern Sudan. The floating laboratory also helped the staff of the Sleeping Sickness Commission and greatly enhanced the work of the Sudan Central Sanitary Board. ${ }^{27}$

\section{NETWORKING AND COLLABORATION WITH THE TROPICAL MEDICAL COMMUNITY WORLDWIDE}

Balfour's networking with leading figures of tropical medicine of his time, such as Professor William Boog Leishman (the co-discoverer of Leishman-Donovan bodies) and his own mentor, Patrick Manson, helped to secure excellent medical staff to work in Khartoum. Balfour's networking energies secured continuing interest from the tropical medical community of his varied work, not only in medicine but in other areas like entomology, medical anthropology, veterinary, biological and chemical research. The work of Balfour in Sudan was seen and regarded with great respect by his peers and 
associates in the tropical and wider medical community. Following his resignation from his post in Khartoum, Andrew Balfour moved to London to take up the post of Director of the Wellcome Bureau of Research. He then became director of the London School of Hygiene \& Tropical Medicine and oversaw the building of the new school. He was knighted in 1930. From 1927, he suffered from depression and that eventually led to his death in 1931.

Several satellite branches of the WTRL were opened throughout the 1920s. A branch was opened at Wad Medani in 1924, primarily to focus on conducting soil and agricultural research. Another was opened at Atbara in January 1925, mainly to assist with the chemical work of the Department of Railways and Steamers of the Sudanese Government. In 1927, the WTRL was moved permanently from the Gordon Memorial College to be housed in the newly built complex of the Stack Laboratory in Khartoum. This was built in memory of Sir Lee Stack who was assassinated in Cairo in 1924. In 1932, Wellcome made an offer to the Sudanese Government to build a new laboratory on the Nile and offered to finance the whole enterprise including buildings and equipment. The offer was considered by the Government of Sudan but there was disagreement over the details of the project. Wellcome insisted on a first class riverfront building, which did not meet the approval of the government so Wellcome withdrew his offer. It was a personality clash very much highlighted in the letter by N R Udal, the then Principal of the Gordon Memorial College, to Wellcome. ${ }^{28}$

By 1935 the dismantling of the WTRL was taking place. The original chemical laboratories were divided into two sections. The chemical and entomological section was joined to the Geological Surveys of the Public Work Department and was placed under the Department of Agriculture to form the Agricultural Research Institute. To this, the Soil Research Section at Wad Medani was added. The second part of the chemical laboratory became the Chemical Analytical Section which remained in Khartoum and retained the name 'Wellcome Research
Laboratory'. In July 1939, further re-organisation took place. This time, the Wellcome Research Laboratory was transferred to the Sudan Medical Services as part of the research service and the name was modified again to 'Wellcome Chemical Laboratories'. In September 1940, the laboratories were evacuated as 'per war necessities' and was relocated to Shambat, a suburb of north Khartoum. This transfer was done very quickly and at short notice. The new premises were half the size of the previous ones and it was during this move that much of the equipment of the laboratories was either lost or damaged.

After the Second World War, it took until 1948 before the Laboratory was moved back to Khartoum, not to its original premises at the Gordon Memorial College, but to the first floor of the River Hospital. The Laboratory moved to a single floor, which underwent extensive work during May/June 1949 to accommodate the Laboratory. The new premises comprised seven laboratory dark rooms, small laboratories for distillation, milling operations and repairs, storage, four offices and a library. ${ }^{29}$ As D'Arcy stated: 'popular or not, justifiable or not, necessary or not, the discontinuation of Wellcome Tropical Research Laboratories marked the end of an era of medical research in the Sudan'. ${ }^{23}$ However, the legacy of the earlier feats of Wellcome and Balfour in the Sudan were destined never to be forgotten. The earlier public health work of Balfour was the core on which future work was built and that lasted for decades beyond Sudanese independence in 1956. The impact that had on the subsequent development of medical services, research and education remains to the present day. The stronger foundation of the Sudanese health service preand post-Sudanese independence owe much to the earlier work of Balfour and his associates and their successors, as well as to the generosity of Wellcome. The establishment of the Kitchener Medical School in Khartoum in 1924 benefited greatly from the platform laid down by Balfour and his successors. 


\section{REFERENCES}

I Holt PM. The Mahdist State in the Sudan. A study of its origin, development \& its overthrow. Oxford: Oxford University Press; 1958.

2 Churchill WS. The River War. An account of the Reconquest of the Soudan. London: Eyre \& Spottisoode; 1933.

3 Khalil SI. The first hospital in the Sudan I82I-1959. Sudan Med J 20I4; 50: 48-52.

4 Elhadd TA. The first hospital in the Sudan 182I-1959 and the modern medical and health services during the Turco-Egyptian era I82I-I885. Sudan Med J 20|4; 50: III-6.

5 Daly MW. Empire on the Nile:The Anglo-Egyptian Sudan I898-1934. Cambridge: Cambridge University Press; 1986.

6 James R. R. Henry S Wellcome. London: Hodder \& Houghton Ltd; 1995

7 Abdel-Hameed AA. The Wellcome Tropical Research Laboratories in Khartoum (1903-1934): an experiment in development. Med His I997; 4I: 30-58.

8 Wellcome to Wingate, miscellaneous correspondence 1899. Wellcome Archives.

9 Wellcome to Currie, miscellaneous correspondence. Wellcome Archives: GWGA; 171-2, Hb62.

10 Fothergill E. Five years in the Sudan. New York: D Appleton \& Co.; I9II.

II Balfour A. Mosquito work in Khartoum and in the Anglo-Egyptian Sudan generally. First Report of the Wellcome Research Laboratories at the Gordon Memorial College, Khartoum, Education Department, Sudan Government; 1904. p. 14-36.

12 Balfour A. Mosquito work in the Anglo-Egyptian Sudan and in the Anglo-Egyptian Sudan generally. Second Report of the Wellcome Research Laboratories at the Gordon Memorial College, Khartoum, Education Department, Sudan Government; 1906. p. I5-28.

I3 Military Intelligence Reports, Sudan Government, 1903, Royal Commonwealth Section 122/3/4, Cambridge University Library.

I4 Balfour A. Sanitary notes, Khartoum. Third Report of the Wellcome Research Laboratories at the Gordon Memorial College, Khartoum, Education Department, Sudan Government; 1908. p.60-92.

I5 Balfour A. First Report of the Wellcome Tropical Research Laboratories at the Gordon Memorial College Khartoum, Department of Education, Sudan Government. London: Bailliere Tindall \& Cox; 1904. p. 18

I6 Balfour A. Biting and noxious insects other than mosquitoes. First Report of the Wellcome Tropical Research Laboratories at the Gordon Memorial College Khartoum, Department of Education, Sudan Government. London: Bailliere Tindall \& Cox; 1904. p.38-40.
17 Balfour A. Biting and noxious insects other than mosquitoes. Second Report of the Wellcome Tropical Research Laboratories at the Gordon Memorial College Khartoum, Department of Education, Sudan Government. London: Bailliere Tindall \& Cox; 1906. p.29-50.

18 Theobald FV. The mosquitoes of Egypt, The Sudan \& Abyssinia. First Report of the Wellcome Tropical Research Laboratories at the Gordon Memorial College Khartoum, Department of Education, Sudan Government, London: Bailliere Tindal \& Cox; 1904. p.5I-66.

19 Balfour A. Haemogregarine of mammals. Second Report of the Wellcome Tropical Research Laboratories at the Gordon Memorial College Khartoum, Department of Education, Sudan Government. London: Bailliere Tindall \& Cox; 1906. p97-II 2.

20 Laveran. Comptes rendus des seaness de L'Aead des Sciences. 1905; Vol CXLI: 295.

2I Neave S. Leishmania donovani in the Soudan. Brit Med J 1904; I: 1252.

22 Neave S. Report of the travelling pathologist and naturalist. Second Report,Wellcome Research Laboratories at the Gordon Memorial College, Khartoum, Education Department, Sudan Government; 1908. p. I83-204.

23 D'Arcy PF. Laboratory on the Nile: A history of the Wellcome Tropical Research Laboratories. CRC Press; 1999.

24 Balfour A. Second Report of the Wellcome Research Laboratories at the Gordon Memorial College, Khartoum, Education Department, Sudan Government. London: Bailliere Tindall \& Cox; 1906. p. 9-13.

25 Balfour A. Third Report of the Wellcome Tropical Research Laboratories at the Gordon Memorial College Khartoum, Department of Education, Sudan Government. London: Bailliere Tindall \& Cox; 1908. p. 15-23.

26 Wenyon CM. Report of the travelling pathologist and protozolgist. Third Report of the Wellcome Tropical Research Laboratories at the Gordon Memorial College Khartoum, Department of Education, Sudan Government. London: Bailliere Tindall \& Cox; 1908. p. 121-68.

27 Balfour A. Fourth Report of the Wellcome Tropical Research Laboratories at the Gordon Memorial College, Khartoum, Department of Education, Sudan Government. London: Bailliere Tindall \& Cox; | 911 . p.|15-23.

28 Udal to Wellcome. Wellcome Archives; 1930.

29 Ibrahim A. The Wellcome Chemical Laboratories, A contribution to the 8th Annual Conference of the Philosophical Society of the Sudan, January 1960. Robert Kirk Papers, Royal Commonwealth Special Manuscripts I22/2/I, Cambridge University Library. 